\title{
車体傾斜方式の違いによる緩和曲線通過時の乗り心地比較
}

\section{Comparison of Riding Comfort in Transition Curve between Different Tilting Mechanisms}

\author{
○ 学 面川 雅博 （新潟大·院）正 谷藤 克也（新潟大） 正 相馬 仁（新潟大） \\ 正上倉 彰義（JR 東日本）正 加藤 博之（JR 東日本） \\ Masahiro OMOKAWA, Niigata University, 8050, Ikarashi 2-no-cho, Niigata 950-2181 \\ Katsuya TANIFUJI, Niigata University Hitoshi SOMA, Niigata University \\ Akiyoshi UEKURA, East Japan Railway Company, Nisshin-cho2-479, Kita-ku, Saitama-City 331-8513 \\ Hiroyuki KATO, East Japan Railway Company
}

Key Words: Car-body Tilting Vehicle, Tilting Beam, Air Spring, Multi-Body Software, Riding Comfort

\section{1.はじめに}

近年，鉄道は自動車や航空機しの競争が激しくなり，鉄 道車雨の高速化が求められている，特に日本の在来線は地 理的条件加曲線が多く存在子るため, 到達時間の短縮の ためには眿区間での高速化が課題となる。その方策とし て重体傾斜車雨が導入されて赫り，東体傾斜觕が 5 度の振 子梁式と 2 度の空気代衫式が存在する。この中で空気ばね 式は機構が簡筆であるため近年採用が進められている。し かし，空気ば社式伎傾斜角が小さく左右定常加速度を大き く滅ずることができないため，乘り心垉を損なわずによ゙れ

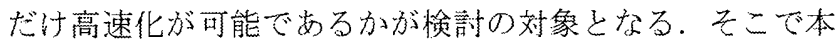
研究ではマルチボディソフトSIMPACK ${ }^{(1)}$ 老用いて車体傾 斜車雨の曲線通過シミュレーションを行い, 緩和曲線中の

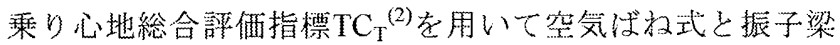
式の乘り心地を評価，比較する。また，空気ばね式につい てはTC 值老改善するための方策を検討寸る。

\section{2. 車両モデル}

2.1 SIMPACKによる解析 SIMPACKは構築されたモデ ルの運動方程式を自動的に生成してシミュレーションが害 行され，任意のバラメータを出力古ることができる。また， SIMPACK で位図 1 に示すように, シミュレーションの車 雨挙動をアニメーションで表示させることも吅能である。 モデルは物体要素(車体，台車など)と作用力要素(軸ばね, 空気ばねなど)の各要素学熬ぎ合わせ，パラメー夕值を入力 することで作成する。なお，本研究で性車体傾斜重雨の制 御を行うために, MATLAB-Simulink との相互シミュレーシ ヨン楼能を用いて制御力を計算する。

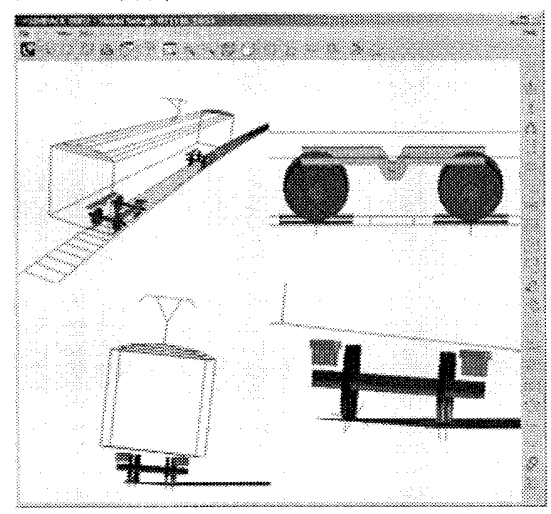

Fig.1 SIMPACK Animation

2.2 車体傾斜車両の車両モデル 振子梁式は, 振子梁を ロール方向の双の1自由度で拘宋主ることで曲線での振り 子動作を可能にして打り，1 車雨で會計36 自由度を有して
いる。振子梁式の制御については，目標傾斜角上妻際の㬋 斜角との差にグインをか忛たものを振子アクチェエータの 制御力としてフィードバックさせる。ここで制御力は空签 嘱れを再現寸るために時定数 1 秒の一次淈れ学生させて 以及.

空気ば称式は1車雨で合計 34 首由度を有している。空気 ば衫式の制御については, 外軌側の内圧老緩和曲線中で 徐々に変化させて車体老持ち上げ，定常四曲線中に招いて 東体が 2 度傾斜するような内圧変化パターンを与えて車体

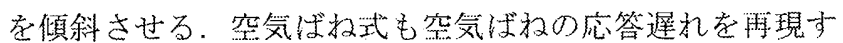
るために，内圧バターンに対して時定数 1 秒の一次遅れ索 発生させたものを䒠際の内压変化とする。

\section{3. 乗り心地の比較}

3.1 乗り心地総合評価指標 $\mathrm{TC}_{\mathrm{T}} \mathrm{TC}_{\mathrm{T}}$ は一つの緩和曲線 に対して適用され，緩和曲線走行時に㧍计万車体振動の四 つの状熊量に対して只れぞれ重双付けをして合成した值で 表される。乗客の姿勢别に定められており，以下の上うな 式で求为ら礼る(2).

$$
\text { 立位: } \mathrm{TC}_{\mathrm{T}}=0.6 y_{p}+0.3 y_{j}+0.03 \theta_{p}+0.12 \theta_{j}+0.5
$$

㦄㕸: $\mathrm{TC}_{\mathrm{T}}=0.4 y_{p}+0.4 y_{j}+0.02 \theta_{p}+0.04 \theta_{j}+0.8$

ここで $y_{p}$ は左右振動加速度最大值, $y_{j}$ は左右ジャーク最大值, $\theta_{p}$ は口ール角速度最大值， $\theta_{j}$ は口ール角加速度最大值であ る。この計算結果唯 3 を超えると不快，2以下であれば問 題なしという評価となる。

3.2 解析条件実際の路線を想定した連続曲線の走行シ ミュレーションを行い，乘り心地索比較する。この曲線は 3 つの曲線が連続し, 只れぞれ曲線半径, カン下量が $400 \mathrm{~m}$, $105 \mathrm{~mm}$ である。走行速度は本則 $+25 \mathrm{~km} / \mathrm{h} \sigma 100 \mathrm{~km} / \mathrm{h}$ 己劣る。 軌道不整は通り狂いの名考慮する。ここでは評価区間を図

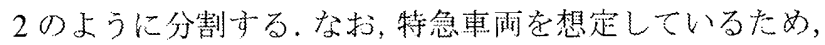

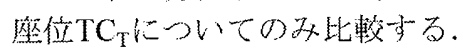

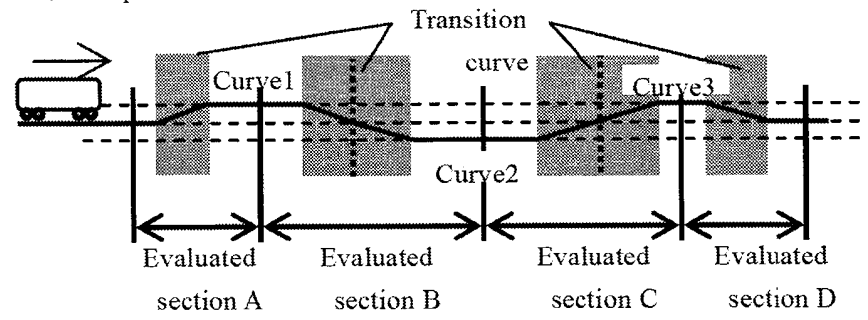

Fig. 2 Track condition and evaluated sections

3.3 解析結果の比較 四3にそれぞれの傾斜方式における 左右加速度とロール角速度のシミュレーション綃果を, 表 1 にシミュレーション結果より算出した $\mathrm{TC}_{\mathrm{T}}$ 示す。四 


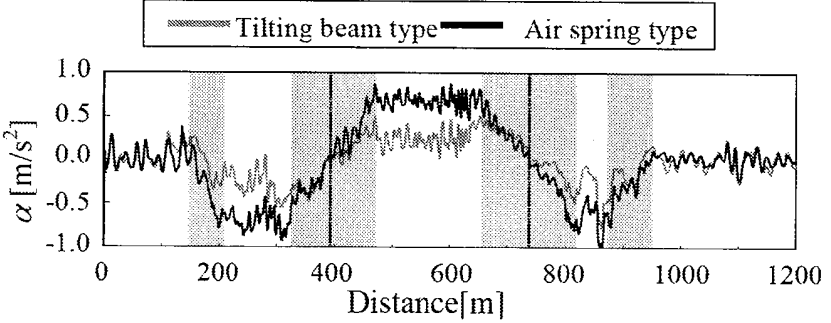

(a)Lateral acceleration

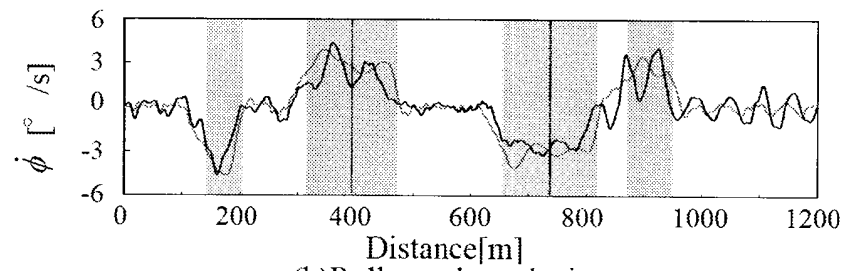

(b) Roll angular velocity

Fig. 3 Comparison of simulation results between the tilting mechanisms

Table 1 Comparison of $\mathrm{TC}_{\mathrm{T}}$ values

between the tilting mechanisms

\begin{tabular}{|c|c|c|c|c|c|}
\hline \multicolumn{2}{|c|}{ Evaluated section } & $\mathrm{A}$ & $\mathrm{B}$ & $\mathrm{C}$ & $\mathrm{D}$ \\
\hline \multirow{2}{*}{$\mathrm{TC}_{\mathrm{T}}$} & Tilting beam type & 1.48 & 1.48 & 1.49 & 1.61 \\
\cline { 2 - 6 } & Air spring type & 1.64 & 1.64 & 1.54 & 1.79 \\
\hline
\end{tabular}

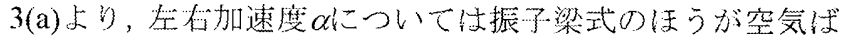

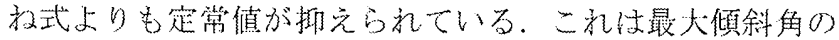
違いに上るものである。文た图 3(b)に示さ礼る上らに，振 子梁式は空気ば敉式に比べロール角速度市の変動代抑えら れている。振子梁式は車体が軌道狂いの影響起受けにくい 特徽を持っており，変動の抑制はこの效果によるもの上藕 えられる。 $\mathrm{TC}_{\mathrm{T}}$ 算出結果充ると，どの評価区間に执いて

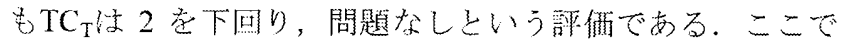
雨者莸比較才るし，空気ば权式のほうが大きい值となって いる，空気ば权式は最大東体傾斜角が小さいためy く滅ずることができず，乙れがTC ものといえる。

\section{4. 空気ばね式におけるTC、値の改善}

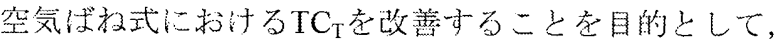
内压変化バターンを変化さ持たシミュレーションを行う。 解析条件は前節と同椂上し，バターン変更の效果を検徱す る区閻は比較的軌道不整の影響が小さい評価区間Aと寸る。

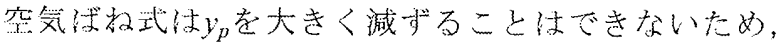

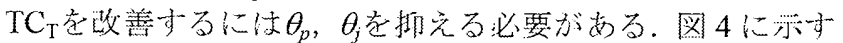

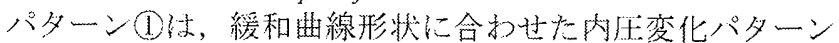

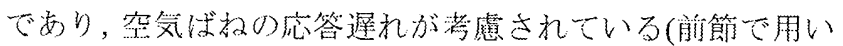
たバターン). $\theta_{p}, \theta_{j}$ 孝小さくするために，このバターン(1) よりも前後 1 秒ずつ㑯斜時間を伸代したハターン(2だシミ ニレーション老行い， $\mathrm{TC}_{\mathrm{T}}$ 苍算出した。素 2 より雨者孛比 較すると， $\theta_{p} ， \theta_{j}$ を小さく寸ることができているものの， $\mathrm{TC}_{\mathrm{T}}$ 仿バターン(1)上回っている。これ傎斜動作がパタ

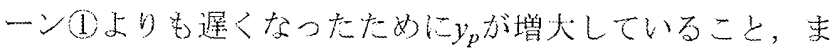
たバターンのよりも早い段階で傾斜の動作が始走るため四

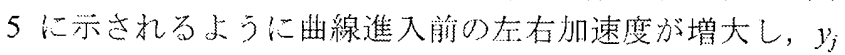

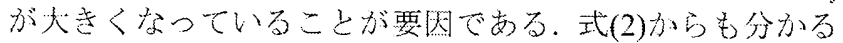

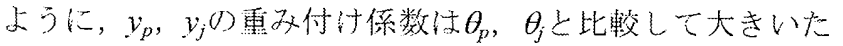
め, $y_{p}, y_{j}$ の增大は $\mathrm{TC}_{\mathrm{T}}$ の增加に大きく影響している。

$y_{j}$ 在小さく古石ために，バターン(1)の後方のみ堂1秒伸

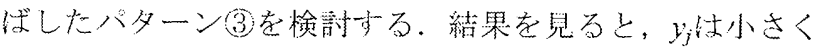

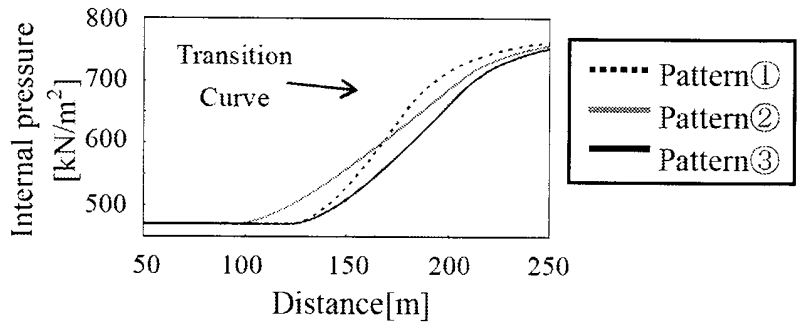

Fig.4 Actual change of internal pressure

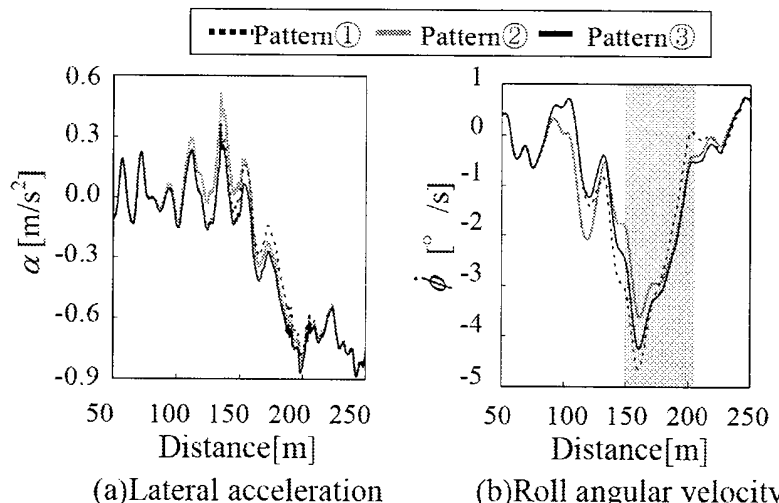

Fig. 5 Comparison of simulation results between the different patterns

Table 2 Parameter values and $\mathrm{TC}_{\mathrm{T}}$ values

\begin{tabular}{|c|c|c|c|}
\hline Pattern & (1) & (2) & (3) \\
\hline$y_{p}\left[\mathrm{~m} / \mathrm{s}^{2}\right]$ & 0.87 & 0.89 & 0.89 \\
\hline $\begin{array}{ll}y_{j} & {\left[\mathrm{~m} / \mathrm{s}^{3}\right]}\end{array}$ & 0.62 & 0.79 & 0.7 \\
\hline $\begin{array}{lll}\theta_{p} & {[} & 0\end{array}$ & 4.65 & 3.63 & 4.26 \\
\hline$\theta_{j} \quad\left[\begin{array}{ll}3 & \left./ \mathrm{s}^{2}\right] \\
\end{array}\right.$ & 3.81 & 3.09 & 3.85 \\
\hline $\mathrm{TC}_{\mathrm{T}}$ & 1.64 & 1.67 & 1.67 \\
\hline
\end{tabular}

なったものの，傾斜に要する时閐が短くなったため $\theta_{p}, \theta_{j}$

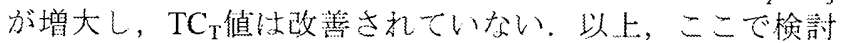

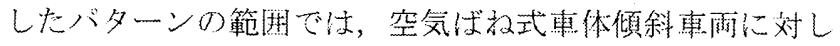
て $\mathrm{TC}_{\mathrm{T}}$ 振子梁式のそれに近つけるには至らなかった。

\section{5.まとめ}

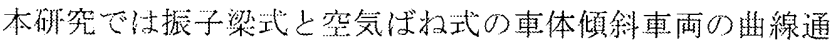
過シミュレーションを行い，乗り心地総合詊価指標 $\mathrm{TC}_{\mathrm{T}}$ 用いて乘り心地を比較した。支た, 空気ばね式の $\mathrm{TC}_{\mathrm{T}}$ 改羓 を目的として，空受代初の间圧変化バターンの変更による 效果在検討し，以下の結㪙孝得た。

(1) 振子粱式上空気ば敞式の乘り心地を $\mathrm{TC}_{\mathrm{T}}$ 老用いて比較 した結果，傾斜鿇腐の違いに上万左右加速度の大きさ の差が影響し，空幽代衫式の值が振子梁式上りも大き い值よなった。

(2) 空気ばね式について，今回愉䞑した内圧变化バターン の範目では $\mathrm{TC}_{\mathrm{T}}$ 存振子梁式のそれに近づけるに性至ら なか力た。

\section{参考文献}

(1) G.SCHUPP, 结汃 3 名, The Manchester benchmarks for rail vehicle simulation, Vehicle System Dynamics, Supplement to $31,(1999)$, pp.101-118

（2）鈴木浩明，ほ方 4 名，事体傾斜東雨の緩和曲線歨行時 の乘り心地評価法，鉄道棇研報告(1999) 